\title{
Rev Prof D. W. D. Shaw OBE (1928-2020)
}

In honour of the late Rev Prof D. W. D. Shaw, a founding member of the Editorial Board of Theology in Scotland, we are pleased to publish this tribute by Rev Prof George Newlands. This is a shortened version of George's contribution to the Conference held at New College in 2018 to celebrate Bill's 90th birthday.

We are also pleased to announce that we plan to organise an annual lecture for the next four years in recognition of Bill's contribution to the field of theology in Scotland, and much else. The Trustees of the Hope Trust have generously agreed to sponsor these lectures, which we will publish in the journal. More details to follow.

Alison Jack

Chair of the Editorial Board

\section{Bill Shaw $90^{\text {th }}$ birthday celebration, $4^{\text {th }}$ April 2018}

As we ascended [...], we came face to face with ice and rock, and it became progressively harder. We watched the sun rising over the Alps, throwing an incomparable constellation of high peaks into sharp silhouette. It was a breathtaking spectacle. By 7.30 a.m. we had reached the roof, a few yards from the Cross that stands at the summit. We had made it. We had conquered one of the most famous mountains in the world, 14,691 feet high.

Murdo Ewan Macdonald, Padre Mac, 158 f. ${ }^{1}$

On the Matterhorn in 1958 Bill was thirty years old. Born in Edinburgh in 1928, he was sent to Edinburgh Academy and then to Loretto. Later he

${ }^{1}$ Edinburgh: Birlinn, 2014 
was shipped off to Canada and to Ashbury College, returning to St John's Cambridge for modern languages and law. Bill returned to Edinburgh for a Scottish law degree, and to be Scottish Amateur Squash Champion in 1950, '51 and '52. He practised law in Edinburgh and in London from 1953 to 1957, becoming a partner in his firm and a WS. Though Bill loves Edinburgh, much of his growing up was in rather different cultures. Perhaps that's where he developed the great gift he has had for always respecting, but being able to look beyond, the local orthodoxies.

By 1957 Bill was clearly going places, but it was not to be. He fell into the hands of New College, where his fellow students included Duncan Forrester. Ordained in the Church of Scotland in 1960, he was Assistant Minister at St George's West, and was involved in the Cephas youth project. In 1962 he was one of two Church of Scotland official Observers at Vatican II - a huge compliment to his exceptional skills. The following year he was appointed to a lectureship in theology in New College. His lectures were meticulously prepared. His tutorials were searching but encouraging. He had seminars on theology and literature in his home, which people said were just brilliant. Recently I came across some letters from Bill - carefully thought through, immensely helpful counsel. I occasionally stumble upon other folk who have been supported in all sorts of circumstances through his kindness, and no-one knows anything about it.

Bill Shaw spent sixteen years in the New College department, latterly as Principal and Dean of the Faculty of Divinity. He soon gained a wellearned reputation as an administrator, keeping cool when all around him were dissolving into very stable geniuses. This was a time too of increasing involvement in the affairs of the Church of Scotland at large, notably for the judicial commission of the General Assembly. In 1979 Bill was appointed Professor of Divinity at St Andrews, restoring to St Mary's not a little of the mantle of the legendary Donald Baillie. Here again, we find so many St Mary's students expressing profound appreciation. He presided over the $450^{\text {th }}$ anniversary of St Mary's in 1991, the year in which he became a DD of Glasgow.

The previous year he fulfilled another taxing assignment in presiding over the final session of the General Assembly of the WARC in Korea. Bill served the church for 14 years on the WARC committee. In the universities he gave the Croall Lectures in Edinburgh and the Alexander Robertson Lectures in Glasgow, was a founder and for a time Editor of 
Theology in Scotland and a Visiting Fellow at Fitzwilliam College, Cambridge. In America he was a visiting Professor in Texas - not to mention a Squash champion once again, and a member of the Highlands Institute for American Philosophy and Theology. In 1996 Peter McEnhill and George Hall edited a Festschrift volume, The Presumption of Presence, and in 2005 St Andrews added a second DD.

More recently Her Majesty made Bill OBE, for charitable services. He had been a superb Chairman of the Hope Trust. But here was the only public mention of the fact that for many years Bill has been making very substantial financial contributions to Scottish universities, as well as many gifts to individuals in need, under an anonymous trust. In a world increasingly given to a dazzling image-conscious culture. Bill has lived a modest life for more than half a century, very active as a member of Cramond Kirk. He has conducted endless baptisms, weddings and funerals for friends and former students, visiting the sick, doing readings for the blind. He has been Chaplain of the R\&A Golf Club in St Andrews, and he still swims at the Edinburgh Sports Club.

In his writings, characteristically he explains issues with careful lucidity. He affirms traditional doctrine, then takes things further in a plastic reshaping. He is always his own man, finding value where he chooses - not least in a nuanced appreciation of aspects of process thought. I wish we had more in print. But see his blog, ${ }^{2}$ from which I allow myself just one extract:

The Christian doctrine of incarnation recognises that the most profound aspect of God's love is the idea of God's identification with the human condition. To identify with some-one is not to cease to be oneself but to try to put oneself in some-one else's shoes. As humans, we can only begin to do something like that with people we care about - children, families, some-one we love. As far as others are concerned, we lack the knowledge, the imagination to identify completely, to put ourselves in their skins, as it were. Only a perfect love could identify completely - and that is exactly what Christians see in the life, death and resurrection of Christ - God himself, coming the whole way, treading the path of identification with stupid, struggling humanity, with no holds barred, no

\footnotetext{
${ }^{2}$ https://web.archive.org/web/20191228221134/http://www.dwdshaw.co.uk/
} 
guarantees, no hotline of rescue or defence: a path of identification which does not end, even at the Cross.

A Kind of Christianity, Chapter Four

In the 1996 Festschrift volume John McIntyre speaks of Bill's pastoral skills, 'born of a great kindliness of heart and amply in evidence in the wide range of his administrative responsibilities.' His great kindliness never ending, his eirenic spirit - utterly refreshing in the playground of the theologians, his Christian grace - for this there are no words. All we can do is celebrate a friend who is absolutely not a celebrity. His is absolutely a road less travelled. The Revd Professor D. W. D. Shaw, 90 not out.

George Newlands 